\title{
How ice cream manufactured with concentrated milk serves as a protective probiotic carrier? An in vitro gastrointestinal assay
}

\author{
Callebe CAMELO-SILVA ${ }^{1}$ (D), Eulália Lopes da Silva BARROS ${ }^{1}$, Silvani VERRUCK², Bruna Marchesan MARAN ${ }^{3}$, \\ Maria Helena Machado CANELLA ${ }^{1}$, Erick Almeida ESMERINO ${ }^{4,5}$, Ramon SILVA ${ }^{5}$, Elane Schwinden PRUDENCIO ${ }^{1,2 *}$ (D)
}

\begin{abstract}
The skimmed milk was previously concentrated by the block freeze concentration and, thus, used in the manufacture of an ice cream sample with Bifidobacterium BB-12 addition. This sample was compared with two control samples, one ice cream manufactured with skimmed milk, and the other an MRS broth, which supplies an excellent base for comparison of the bacterial survival. All three samples were submitted to the in vitro gastrointestinal assays from the mouth to the large intestine. The initial Bifidobacterium BB-12 viable cell count ( $>8 \log \mathrm{CFU} / \mathrm{g}$ or $\mathrm{mL}$ ) of both ice cream samples ensured their classification as probiotic products. This behavior was noted during all in vitro steps (from the mouth until the colon). From the mouth to the ileum was observed that both ice creams showed a slight oscillatory probiotic count. For the ice cream manufactured with concentrated milk, it was observed a high bifidobacteria protective effect in the descending colon, with probiotic viable cells count and recovery rate values equal to $9.88 \mathrm{log} \mathrm{CFU} / \mathrm{g}$ and $112.02 \%$, respectively. Finally, it was possible to conclude that as well as the ice cream with milk, the concentrated milk served as a succesful probiotic carrier.
\end{abstract}

Keywords: probiotic ice cream; functional food; freeze concentration; Bifidobacterium BB-12; probiotic viability; simulation gastrointestinal conditions.

Practical Application: The potential of using concentrated milk for the production of probiotic ice cream.

\section{Introduction}

Functional foods are food products to be consumed as part of a balanced diet, such as dairy products containing probiotics (Rodrigues et al., 2012). Zendeboodi et al. (2020) defined the probiotics as 'viable or inviable microbial cell (vegetative or spore; intact or ruptured) that is potentially healthful to the host'. However, it is known that the functional properties of a probiotic can be influenced by the food carriers used in probiotic delivery (Ranadheera et al., 2012).

Milk products, such as fermented milk, yogurt, cheese and ice cream have received considerable attention as functional food (Mousavi Khaneghah et al., 2020). Al et al. (2020) verified the effect of recombinant microbial transglutaminase enzyme on the physicochemical properties of ice cream. Ghandehari Yazdi et al. (2020) produced a functional ice cream by the addition of microcapsules of pistachio peel extract, and observed that phenolic content and antioxidant activity increased about 2.0 and 3.7 fold, respectively, compared with the control samples. Mehditabar et al. (2020) observed that the pumpkin puree increased color, intensity of fruit flavors, firmness, total phenolic content, dietary fiber, and antioxidant activity of ice cream. Akalın et al. (2018) related that ice cream has good potential to be used as a probiotic vehicle, because of its composition, as well as its pleasant taste and attractive texture. Furthermore, these authors affirmed that probiotics could be able to survive in frozen systems, such as ice cream matrix because nutritive constituents of milk are present in its composition. Balthazar et al. (2018) evaluated the effect of the Lactobacillus casei 01 and inulin addition on sheep milk ice cream during storage $\left(-18^{\circ} \mathrm{C}, 150\right.$ days). Ranadheera et al. (2012) affirmed that the delivery of probiotics in a suitable food matrix is one of the most appropriate means of maximizing probiotic efficacy. These authors also pointed out that the food may provide some protection to probiotics by reducing their physical exposure to the harsh gastrointestinal environment. Muñoz et al. (2019) stated that the probiotic bacteria need to tolerate the different adverse conditions encountered in the manufacture of a product; beyond they also must survive harsh conditions during gastrointestinal conditions. Studies with in vitro methods in comparison with human in vivo studies are considered faster; less expensive; highly reproducible; allow for a large number of samples, being measured in parallel for screening purposes; allow the choice of controlled conditions; and have no ethical restrictions (Calvo-Lerma et al., 2019; Minekus et al., 2014). Among these factors, simulated digestion methods typically include the oral, gastric, and small intestinal phases and occasionally large intestine conditions. These methods try to mimic physiological conditions 
in vivo, taking into account the presence of digestive enzymes and their concentrations, $\mathrm{pH}$, digestion time, digestive fluids, temperature, and peristaltic movements, as usually occurs during human digestion (Minekus et al., 2014). Grom et al. (2020) observed a good correlation between in vitro and in vivo data, in which the type of dairy matrix affects the anti-hyperglycemic activity.

Muñoz et al. (2019) used successfully soft fresh cheese manufactured from milk concentrated by the block freeze concentration process, as a protective matrix on probiotic survival under in vitro gastrointestinal conditions. In contrast with other concentration processes, in the block freeze concentration, the whole solution is frozen and partially thawed to recover the concentrated liquid fraction using low temperature. Because of these low temperatures are minimized the chemical degradation of milk constituents (Munoz et al., 2017). Petzold et al. (2015) stated that the industrial future of the freeze concentration has been associated more with developments in the configuration of one-step systems, such as the block freeze concentration. Another advantage described by these authors, which is related to the one-step system, is the simplicity in terms of the construction and operation mechanism. In this context, the present work aims to elucidate if it is possible for an ice cream manufactured with concentrated skimmed milk, from the block freeze concentration process, to serve as a protective probiotic carrier through in vitro gastrointestinal conditions.

\section{Materials and methods}

\subsection{Material}

A freeze-dried probiotic culture composed of Bifidobacterium BB-12 (Bifidobacterium animalis subsp. lactis, Chr. Hansen, Honsholm, Denmark) was used for the production of probiotic cream creams. For the preparation of two ice creams were used the following ingredients skimmed milk (UHT - Ultra High Temperature, Tirol ${ }^{\oplus}$, Treze Tílias, SC, Brazil) (8.05 g/100 g

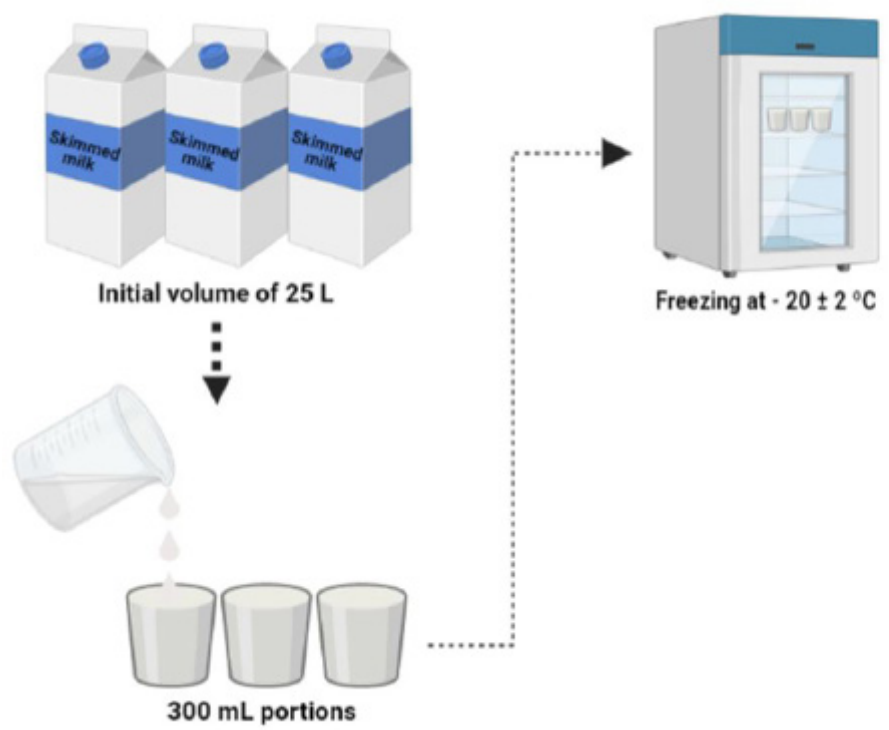

of total solids), commercial sucrose (União ${ }^{\circledR}$, São Paulo, SP, Brazil), milk cream (45 g per $100 \mathrm{~g}$ of fat, Tirol', Treze Tílias, SC, Brazil), and sodium chloride (Cristalino ${ }^{\circledR}$, Mossoró, RN, Brazil). During mouth, esophagus/stomach, duodenum, until ileum step were used the following enzymes: $\alpha$-amylase (28.75 U/mg protein), pepsin from porcine gastric mucosa (400 U/mg protein), and pancreatin from porcine pancreas (digestive power - $8 \mathrm{X}$ USP specifications); besides the bovine bile salt ( $28.75 \mathrm{U} / \mathrm{mg}$ protein), all purchased from Sigma-Aldrich (St. Louis, MO, USA). For the colon steps, a suitable medium containing the major compounds were prepared through bacteriological peptone, yeast extract, tryptone, and Tween 80 acquired from Oxoid (Hampshire, $\mathrm{UK})$. To mimic colon conditions were also employed $\mathrm{NaCl}$, $\mathrm{KH}_{2} \mathrm{PO}_{4}, \mathrm{MgSO}_{4} \cdot 7 \mathrm{H}_{2} \mathrm{O}, \mathrm{KCl}$, citrus pectin, casein, starch, and L-cysteine, which were purchased from Sigma-Aldrich (St. Louis, MO, USA). MRS broth (Difco, Sparks, USA) was used as a control sample and in the preparation of bifidobacteria suspension. MRS agar (Difco, Sparks, USA), sodium propionate (Fluka, Neu-Ulm, Germany), lithium chloride (Vetec, Rio de Janeiro, Brazil), and AnaeroGen ${ }^{\circledR}$ (Oxoid, Hampshire, UK) were used in bifidobacteria viable cell count.

\subsection{Concentrated manufacture}

The block freeze concentration process (Figure 1) was realized in obtaining the skimmed milk concentrated. An initial volume of $25 \mathrm{~L}$ of skimmed milk was divided into $300 \mathrm{~mL}$ portions, which were subjected to freezing at $-20 \pm 2{ }^{\circ} \mathrm{C}$ in a freezer (Electrolux, FE 18, São Carlos, Brazil). According to the protocol used by Munoz et al. (2017), the skimmed milk was frozen and $50 \%$ of its initial volume was thawed at $20 \pm 2{ }^{\circ} \mathrm{C}$. The thawed liquid, denoted as concentrated, was used in the formulation of one of the ice creams. This procedure was carried out aiming to obtain a concentrated with total solids content increase of milk approximately $20 \%$. After this procedure, it

Figure 1. Skimmed milk block freeze concentration process. 
was obtained milk concentrated with $10.27 \mathrm{~g} / 100 \mathrm{~g}$ of total solids content.

\subsection{Probiotic suspension preparation}

In order to obtain the stock solution, freeze-dried probiotic cells of Bifidobacterium BB-12 were rehydrated in sterile skimmed milk $(25 \mathrm{~g} / \mathrm{L})$ and stored in sterile glass vials at $-20 \pm 2{ }^{\circ} \mathrm{C}$ (Fritzen-Freire et al., 2012). Stock solution was added to the MRS broth modified with $0.2 \mathrm{~g} / 100 \mathrm{~g}$ of lithium chloride and $0.3 \mathrm{~g} / 100 \mathrm{~g}$ of sodium propionate additions and submitted to incubation period $\left(37 \pm 1{ }^{\circ} \mathrm{C}\right.$ for $\left.48 \mathrm{~h}\right)$ in anaerobic jars with AnaeroGen ${ }^{\circ}$. After the incubation period, bifidobacteria cells were harvested by centrifugation $(1,000 \mathrm{xg})$ for $10 \mathrm{~min}$ (centrifuge from Nova Técnica, São Paulo, Brazil) at a temperature of $25 \pm 1{ }^{\circ} \mathrm{C}$. The probiotic cell pellet was washed twice with a saline solution $(0.9 / 100 \mathrm{~g})$. Probiotics suspensions were obtained when bifidobacteria cell pellets were suspended in $20 \mathrm{~mL}$ of the skimmed milk, in $20 \mathrm{~mL}$ of the concentrated manufactured, and $20 \mathrm{~mL}$ of the MRS broth, respectively. Bifidobacterium BB-12 viable cell counts were done for each one probiotic suspension.

\subsection{Ice cream manufacture}

Two ice creams mixes were manufactured with skimmed milk $(61.7 \mathrm{~g} / 100 \mathrm{~g})$ or concentrated manufactured from freeze concentration process $(61.7 \mathrm{~g} / 100 \mathrm{~g})$, and denoted as ice cream 1 or ice cream 2, respectively. The other ingredients added in both ice cream mixes were $22.20 \mathrm{~g} / 100 \mathrm{~g}$ of commercial sucrose, $16.04 \mathrm{~g} / 100 \mathrm{~g}$ of milk cream, and $0.06 \mathrm{~g} / 100 \mathrm{~g}$ of sodium chloride. The mixes were pasteurized at $75 \pm 2{ }^{\circ} \mathrm{C}$ for 30 min using a water bath (Model DI950M, Dist, Florianópolis, SC, Brazil), and cooled to $4 \pm 1{ }^{\circ} \mathrm{C}$. In sequence, probiotic suspensions previously prepared were added into their respective ice cream mix, whipped, and frozen in an ice cream maker (Cuisinart ICE 21, Nova Jersey, USA). At a drawing temperature of $-6 \pm 1{ }^{\circ} \mathrm{C}$, ice creams were packaged into $500 \mathrm{~mL}$ plastic containers and stored at $-18 \pm 2{ }^{\circ} \mathrm{C}$ until the analysis. Bifidobacterium BB-12 viable cell counts were realized for ice cream 1 and ice cream 2 samples.

\subsection{In vitro gastrointestinal procedure}

In vitro gastrointestinal procedure was carried out in triplicate following methodology adapted by Barretta et al. (2019). This methodology simulates the conditions that exist during the digestive process, which begins in the mouth, and sequentially follows to the esophagus-stomach, duodenum, ileum, and ascending, transverse and descending colon (large intestine). The conditions used in the experiment are summarized in Figure 2. Therefore, enzyme solutions were sterilized by filtration using a $0.22 \mu \mathrm{m}$ membrane filter (MF-Millipore, Billerica, MA, USA), and kept in an ice bath until the analysis. The $\mathrm{pH}$ values were controlled using $\mathrm{NaHCO}_{3}(1 \mathrm{~mol} / \mathrm{L})$ or $\mathrm{HCl}(1 \mathrm{~mol} / \mathrm{L})$. The temperature $\left(37 \pm 1{ }^{\circ} \mathrm{C}\right)$ and peristaltic movements of the human digestive system were simulated by a water bath (Dist DI950M, Florianópolis, SC, Brazil). The colon steps (ascending, transverse, and descending) were realized under anaerobic conditions.
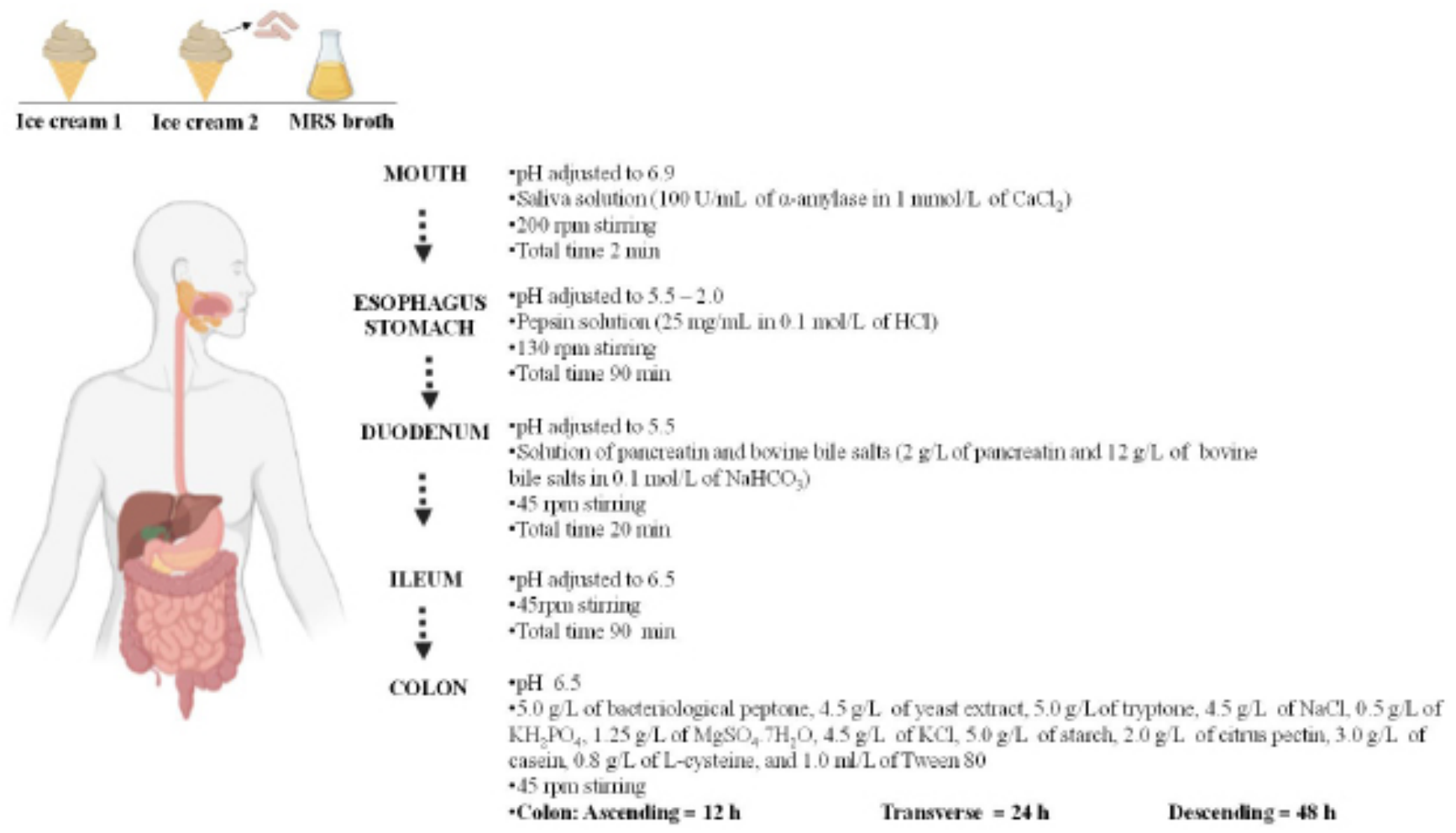

Figure 2. The protocol used during in vitro gastrointestinal steps for both ice creams samples and MRS broth (control sample). 
In vitro gastrointestinal procedures were done with $25 \mathrm{~g}$ of each ice cream sample (ice cream 1 and ice cream 2). Such as the MRS broth supply an excellent base for comparison of bacterial strain behavior, it was used for the survival of bifidobacteria under gastrointestinal conditions. As realized for the ice creams samples, $25 \mathrm{~mL}$ of the MRS broth (control) with $20 \mathrm{~mL} / \mathrm{L}$ bifidobacteria suspension addition was also submitted to the in vitro gastrointestinal experiment. Therefore, the ice cream 1 , the ice cream 2, and the control sample (MRS broth) were evaluated by in vitro gastrointestinal conditions.

\subsection{Bifidobacterium BB-12 performance}

Bifidobacterium BB-12 viable cell count was realized for three probiotic suspensions (skimmed milk, concentrated, MRS broth) added into ice creams, as well as for ice cream 1 and 2 samples. The same analysis was done after each one in vitro gastrointestinal step. As sample volume increase after in vitro gastrointestinal procedure, each sample dilution was corrected with peptone water $(0.1 \mathrm{~g} / 100 \mathrm{~g})$ until $225 \mathrm{~mL} / 25 \mathrm{~g}$ of each ice cream or $225 \mathrm{~mL} / 25 \mathrm{~mL}$ of MRS broth and blended using a bag mixer 400 (Interscience, St. Nom, France).

According to Vinderola \& Reinheimer (2000), all samples were serially diluted with peptone water $(0.1 \mathrm{~g} / 100 \mathrm{~g})$ and plated in triplicate on MRS agar modified with the addition of lithium chloride $(0.2 \mathrm{~g} / 100 \mathrm{~g})$ and sodium propionate $(0.3 \mathrm{~g} / 100 \mathrm{~g})$. The plates were incubated in anaerobic jars with AnaeroGen ${ }^{\circ}$ at $37 \pm 1^{\circ} \mathrm{C}$ for $72 \mathrm{~h}$. Bifidobacteria viable cell count was carried out in triplicate and expressed as log colony-forming units per gram $(\log \mathrm{CFU} / \mathrm{g})$. Bifidobacteria performance under in vitro gastrointestinal steps was also evaluated by recovery rate (Equation 1) (Guo et al., 2009).

Recovery rate $(\%)=\frac{\mathrm{N}_{1}}{\mathrm{~N}_{0}} \times 100$

where $\mathrm{N}_{1}$ is the Bifidobacterium BB-12 viable cells count (log $\mathrm{CFU} / \mathrm{g}$ ) after exposure to each in vitro gastrointestinal step, and
$\mathrm{N}_{0}$ is bifidobacteria viable cells count $(\log \mathrm{CFU} / \mathrm{g})$ before in vitro gastrointestinal step.

\subsection{Statistical analysis}

Statistical analysis was realized using STATISTICA 13.3 software (TIBCO Software Inc., Palo Alto, CA, USA). One-way analysis of variance (ANOVA) followed by Tukey test was performed to determine the significant differences $(p<0.05)$ between the samples. Data were expressed as mean \pm standard deviation.

\section{Results and discussion}

Table 1 shows Bifidobacterium BB-12 viable cells count performance for MRS broth (control sample), ice cream 1, prepared with skimmed milk, and ice cream 2 , with the concentrated from the first step of skimmed milk freeze concentration process, after their exposures to each in vitro gastrointestinal steps. Bifidobacteria initial samples count ensured that all samples, including MRS broth (control sample), can be classified as a probiotic product. According to Hill et al. (2014) for a product be considered with potential benefits to the human health, it must have a viable cell counts equal to or $>6 \log \mathrm{CFU} \mathrm{g}^{-1}$. Therefore, we confirmed that both ice creams were a protective matrix for bifidobacteria during the adverse conditions encountered in the manufacture of samples. Kalicka et al. (2019) investigated the effect of polyols on physical and sensory properties of probiotic ice cream, as well as the survival of Bifidobacterium BB-12 during freezing over 28 days of frozen storage. These authors observed that the viable bifidobacteria counts remained above $8 \log \mathrm{cfu} / \mathrm{g}$ in all samples.

The bifidobacteria performance can be viewed in Figure 3. It must be highlighted that the MRS sample as control is necessary because according to Madureira et al. (2011) the behavior of probiotic bacteria in the MRS broth provides an excellent base for comparison, being able to assess the protective effect of the ice cream with different compositions. Furthermore, the short duration and neutral $\mathrm{pH}$ conditions found in the mouth step would not have been expected to impact bifidobacteria viable cells

Table 1. Results expressed as mean \pm standard deviation of Bifidobacterium BB-12 viable cells count (log UFC/g) from MRS broth (control sample), ice cream 1 sample and ice cream 2 sample after their exposures to each in vitro gastrointestinal step.

\begin{tabular}{|c|c|c|c|c|}
\hline & & MRS broth & Ice cream 1 & Ice cream 2 \\
\hline Probiotic suspension & & 9.81 & 10.10 & 9.82 \\
\hline Initial sample count & & $8.81 \pm 0.07^{\mathrm{cB}}$ & $9.10 \pm 0.13^{\mathrm{bA}}$ & $8.82 \pm 0.13^{\mathrm{c}, \mathrm{dB}}$ \\
\hline Mouth & & $8.61 \pm 0.08^{\mathrm{dA}}$ & $8.53 \pm 0.06^{\mathrm{dA}}$ & $8.63 \pm 0.08^{\mathrm{d}, \mathrm{eA}}$ \\
\hline Esophagus/stomach & & $8.61 \pm 0.13^{\mathrm{dB}}$ & $8.85 \pm 0.04^{\mathrm{cA}}$ & $8.68 \pm 0.11^{\mathrm{c}, \mathrm{d}, \mathrm{eB}}$ \\
\hline Duodenum & & $8.64 \pm 0.05^{\mathrm{dA}}$ & $8.61 \pm 0.04^{\mathrm{dA}}$ & $8.60 \pm 0.03^{\mathrm{eA}}$ \\
\hline Ileum & & $8.63 \pm 0.06^{\mathrm{dB}}$ & $8.76 \pm 0.06^{\mathrm{cA}, \mathrm{B}}$ & $8.78 \pm 0.06^{\mathrm{cA}}$ \\
\hline \multirow{3}{*}{ Colon } & Ascending & $9.75 \pm 0.01^{\mathrm{aA}}$ & $9.41 \pm 0.32^{\mathrm{a}, \mathrm{bB}}$ & $9.21 \pm 0.10^{\mathrm{bC}}$ \\
\hline & Transverse & $9.56 \pm 0.11^{\mathrm{bA}}$ & $9.73 \pm 0.17^{\mathrm{aA}}$ & $9.20 \pm 0.04^{\mathrm{bB}}$ \\
\hline & Descending & $8.54 \pm 0.09^{\mathrm{dB}}$ & $9.64 \pm 0.04^{\mathrm{aB}}$ & $9.88 \pm 0.40^{\mathrm{aA}}$ \\
\hline
\end{tabular}

a-e Within a column, different superscript lowercase letters denote significant differences $(p<0.05)$ among the different steps of the simulated gastrointestinal conditions for each sample. ${ }^{-B}$ Within a line, different superscript uppercase letters denote significant differences $(p<0.05)$ among the same sample after the simulated gastrointestinal conditions step. Probiotic suspension represents the bifidobacteria viable cells count added into the ice cream mixes and MRS broth. Ice cream $1=i c e$ cream mix was prepared with skimmed milk; Ice cream 2 = ice cream mix was prepared with concentrated manufactured from the first stage of the freeze concentration process. Three experimental trials were carried out and three replicates of each sample were analyzed each time. 


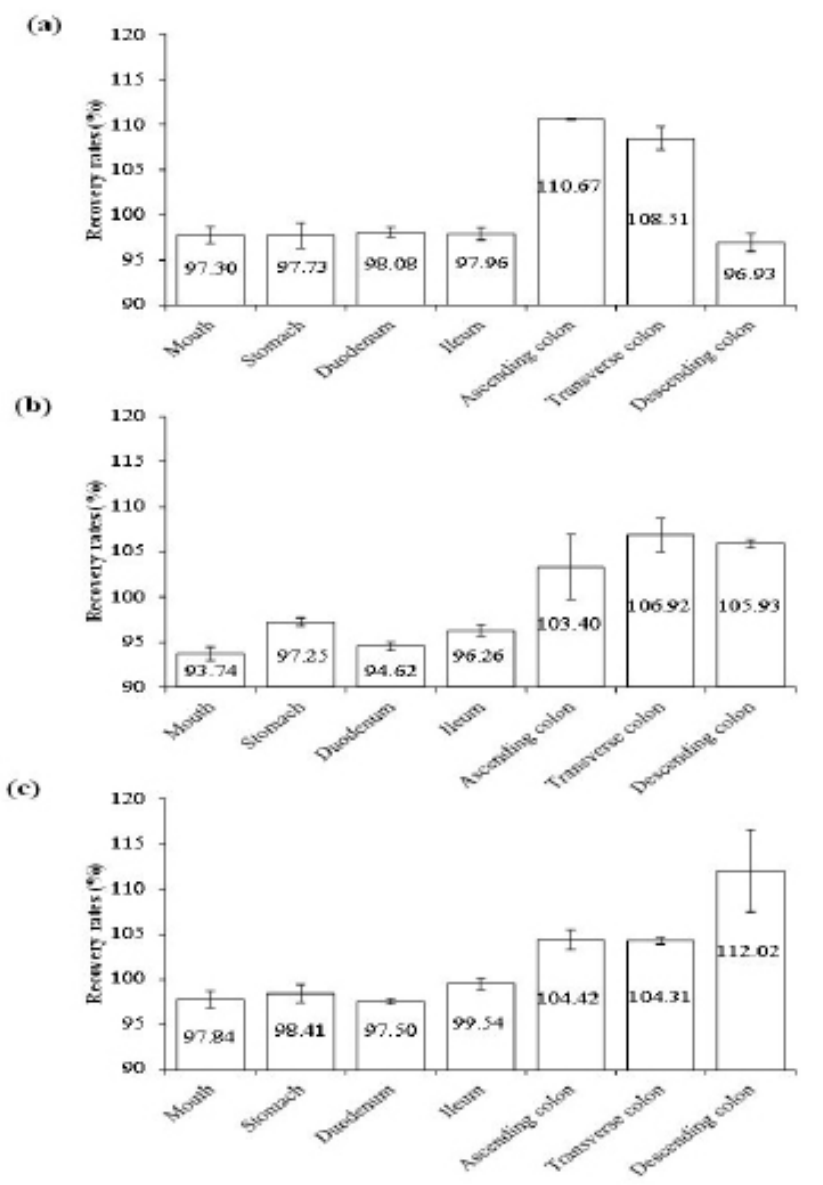

Figure 3. Bifidobacterium BB-12 mean survival rate after exposure to each in vitro gastrointestinal steps: (a) control sample (MRS broth); (b) Ice cream 1 = ice cream mix was prepared with skimmed milk; (c) Ice cream 2 = ice cream mix was prepared with concentrated manufactured from the first stage of the freeze concentration process. The error bars represent the standard deviation. Three experimental trials were carried out and three replicates of each sample were analyzed each time.

count. Nevertheless, it was noted that all samples, including MRS broth, showed a decrease $(p<0.05)$ in the bifidobacteria viable cells count in comparison with initial samples count. The recovery of probiotic cultures in the gastric phase of digestion is one of the most crucial steps, due to the low $\mathrm{pH}$ of the medium and the presence of digestive enzymes (Chen et al., 2012). However, at this stage of digestion the probiotic strain remained virtually unchanged in all samples. In ice cream samples ice cream 1 and ice cream 2, the presence of large amounts of total solids such as fat, proteins and other components of milk, may have had physically protected cells against extreme $\mathrm{pH}$ values (cytoplasmic $\mathrm{pH}$ close to neutrality) and against the action of digestive enzymes (Homayouni et al., 2012). According to Picot \& Lacroix (2004) fat confers a protective effect on microorganisms, making it difficult to diffuse $\mathrm{H}^{+}$, organic acids, water and oxygen through the lipid membranes. This behavior was verified by Verruck et al. (2017), where the sample of Bifidobacterium BB-12 microencapsulated with goat's milk that had the highest fat content was the least negatively affected when exposed to the esophagus-stomach conditions. According to Magariños et al. (2007), the chemical composition of dairy products is important in maintaining the metabolic activity of probiotic cells. Ranadheera et al. (2012) when studying the recovery of Lactobacillus acidophilus LA-5 cells, Bifidobacterium animalis subsp. lactis BB-12 and Propionibacterium jensenii 702 in ice cream and yogurt produced with goat's milk after be exposed to gastrointestinal conditions, found that the ice cream is an excellent carrier matrix and provided a positive influence on the viability retention of each probiotic during gastric transit with simulated gastric juice at $\mathrm{pH}$ 2.0. Balthazar et al. (2021) observed that sheep milk ice cream with Lacticaseibacillus casei 01 or nonfat symbiotic can reduce chemically induced mouse colon carcinogenesis.

After exposure to the duodenum step, it was observed a slight decrease $(p<0.05)$ in bifidobacteria viable cells count in the ice cream 1 sample, and its recovery rate (Figure $3 b$ ). The bile salts act as facilitators of digestion because they are natural detergents that absorb the hydrophobic components of the die. Therefore, the antimicrobial nature of bile arises mainly from its detergent property, which dissolves the bacterial membranes (Madureira et al., 2011). The bile consists mainly of conjugated bile acids, the hydrolysis of which releases taurine or glycine. These acids are toxic and are capable of hindering the development and recovery of probiotic strains (Bustos et al., 2011), affecting the membrane integrity of most Gram-positive and Gram-negative bacteria, causing growth inhibition and even cell death (Kurdi et al., 2006). Despite this, the sample of ice cream produced with freeze concentrated skimmed milk (Ice cream 2) appears to have a protective effect on Bifidobacterium BB-12 cells against the presence of pancreatin and bile salts, once that it was not negatively affected at this stage in relation to the stage of the esophagus-stomach. This same behavior was verified by Muñoz et al. (2019) for the sample of fresh cheese produced with freeze concentrated milk. According to Begley et al. (2005) food components can bind to bile acids, reducing their toxic effect on probiotic cells. And according to Boylston et al. (2004), the increase in $\mathrm{pH}$ to 5.0 may also be a favorable condition for the recovery of bifidobacteria.

In the next step (ileum) was verified an increase $(p<0.05)$ for the bifidobacteria viable cells count and its recovery rate for both ice creams samples. In accordance with Madureira et al. (2011), this behavior occurs because of the neutral $\mathrm{pH}$ used in this step ( $\mathrm{pH} \sim 6.5$ ). In order to colonize the colon, Gu et al. (2019) affirmed that probiotics must survive the harsh conditions during passage through the upper gastrointestinal tract. In particular, they must resist deactivation by the deleterious actions of acids and bile salts within the gut (Gu et al., 2019). The survival stability of bifidobacteria in our samples also could be related to EPS production. Ruas-Madiedo et al. (2009) detected the production of EPS by B. animalis subsp. lactis in the presence of bile. This detection confirmed that bile promoted the synthesis of EPS by B. animalis subsp. lactis, possibly as a mechanism of protection against this toxic compound (Ruas-Madiedo et al., 2009). Moreover, Mousavi Khaneghah et al. (2020) cited that the concept of probiotic is correlated to providing the viable bacterial cell or secreted components from the bacterial cell defined as post-biotics which can be applied in the treatment of intestinal microbiota, disorders and consequently increase in gut permeability. 
As a bacterium that has successfully adapted to living in the colon, Bifidobacterium BB-12 added in the ice cream was also evaluated in the large intestine conditions. Moens et al. (2017) reported that the human colon represents one of the densest microbial ecosystems in terms of bacterial communities, with bifidobacteria representing prominent members of this complex ecosystem. Xu et al. (2019) highlighted that this bacterium has been widely reported to play vital roles to host health and disease, such as the regulation of intestinal microbial homeostasis. It was demonstrated representative growth and recovery rate when the bifidobacteria reached the large intestine. The growth and the recovery rate increased $(p<0.05)$ through the descending colon, showing that the best performance was for the probiotic ice cream 2 sample, manufactured with concentrated skimmed milk. This behavior was extremely important because according to Liao \& Nyachoti (2017) the beneficial effect of probiotics on human health was linked to the modification of the colon bacteria. For ice cream 2, in comparison to the other samples, including the MRS broth, the lowest bifidobacteria viable cells count $(p<0.05)$ and recovery rate $(p<0.05)$ found in ascending and transverse colon, could be due to the bacterium adaptation. Therefore, during the first few hours of simulation in the colon Bifidobacterium BB-12 needs to adapt to the colon environment to produce extracellular enzymes such as carbohydrases to perform lactose hydrolysis. Similarly, caseins had to be reduced to amino acids from the enzymes present in the predecessor's steps. The increase in recovery rate and viable cells count after 48 hours in the colon stage may also be associated with a number of adaptative mechanisms, such as electromagnetic transport system, proton pumps, chaperones capable of repairing damaged proteins, amino acids involved with homogenesis and elements involved in the maintenance of cells (energetic metabolism, cellular envelope) that interfere in acid and bile resistance (Botes et al., 2008). It is important to note that cells that have undergone sub-lethal damage on their DNA or wall, caused by low $\mathrm{pH}$ and bile, for example, can enter a reparative state before being regenerated after replacement and/or repair of damaged molecules (Ben Amor et al., 2002). According to Hoover (2014), cysteine is considered one of the essential amino acids for the metabolic process of the strain involved in this study. Some studies in the literature have also shown that the incorporation of whey proteins ( $\alpha$-lactalbumin and $\beta$-lactoglobulin) into dairy products has a growth promoter activity of the probiotic strain, in order to increase the count of bifidobacteria (Janer et al., 2004; Souza et al., 2017). It is noteworthy that it is at the colon step that the Bifidobacterium BB-12 strain begins to perform its desired biological activities, such as intestinal flora balance, improvement of gastrointestinal motility, and efficacy in the management of lactose absorption, for example, from the adhesion to the wall of the large intestine (Shah, 2007).

Among probiotic food carriers, the use of ice cream as a matrix offer suitable conditions for probiotic bacteria to survive and even grow. According to Mousavi Khaneghah et al. (2020), this fact could be due to some factors such as high water activity, low concentrations of salt, adjusted $\mathrm{pH}$ above 5 , and the absence of common preservatives. Therefore, the ice cream manufactured with the skimmed milk concentrated from the first step of the freeze concentration process could be considered an ideal carrier of the probiotic bacteria Bifidobacterium BB-12 through in vitro gastrointestinal conditions. As the understanding of skimmed milk concentrated used in the ice cream manufacture was possible as a probiotic carrier, helping establish and/or maintain the bifidobacteria viable cells count since the mouth until reaching the colon step. In the end, it was possible to note that both ice creams provide some protection to probiotics by reducing their physical exposure to the harsh gastrointestinal environment. In addition, the concentrated milk in the ice cream manufacture interacted with the probiotic maintaining and improving their performance by in vitro gastrointestinal conditions.

\section{Conclusions}

The initial Bifidobacterium BB-12 viable cell count of all samples ensured their classification as probiotic products. From mouth until ileum step, both probiotic ice creams, manufactured with milk and concentrated milk, showed a slight oscillatory behavior in relation to the probiotic count. However, the most remarkable is that bifidobacteria viable cell counts shown a number that ensured a probiotic product during all in vitro step assays. The greatest protective effect was observed by the ice cream with concentrated milk in the last stage of the in vitro assay, i.e., in the descending colon, which was also represented by the great recovery rate of bifidobacteria. All conclusions are also representing by the great ice cream recovery rates achieved, which were comparable with MRS broth, classified as the best base for probiotic survival. Through the in vitro gastrointestinal assays we concluded that as well as the ice cream with milk, the concentrated milk served as a probiotic carrier.

\section{Acknowledgements}

The authors are grateful to CNPq (National Council for Scientific and Technological Development, Brazil) by the financial support [CNPq, 405965/2016-8], and to CAPES (Coordination of Improvement of Higher Education Personnel, Brazil - Finance Code 001) for the scholarship.

\section{References}

Akalın, A. S., Kesenkas, H., Dinkci, N., Unal, G., Ozer, E., \& Kınık, O. (2018). Enrichment of probiotic ice cream with different dietary fibers: structural characteristics and culture viability. Journal of Dairy Science, 101(1), 37-46. http://dx.doi.org/10.3168/jds.201713468. PMid:29103712.

Al, M., Ersöz, F., Özaktaş, T., Türkanoğlu-Özçelik, A., \& Küçükçetin, A. (2020). Comparison of the effects of adding microbial transglutaminase to milk and ice cream mixture on the properties of ice cream. International Journal of Dairy Technology, 73(3), 578-584. http:// dx.doi.org/10.1111/1471-0307.12707.

Ben Amor, K., Breeuwer, P., Verbaarschot, P., Rombouts, F. M., Akkermans, A. D. L., De, W. M., Ben Amor, K., Breeuwer, P., Verbaarschot, P., Rombouts, F. M., Akkermans, A. D. L., De Vos, W. M., Abee, T., De Vos, W. M., \& Abee, T. (2002). multiparametric flow cytometry and cell sorting for the assessment of viable, injured, and dead bifidobacterium cells during bile salt stress. Applied and Environmental Microbiology, 68(11), 5209-5216. http://dx.doi. org/10.1128/AEM.68.11.5209-5216.2002. PMid:12406706.

Balthazar, C., de Moura, N. A., Romualdo, G. R., Rocha, R. S., Pimentel, T. C., Esmerino, E. A., Freitas, M. Q., Santillo, A., Silva, M. C., Barbisan, 
L. F., Cruz, A. G., \& Albenzio, M. (2021). Synbiotic sheep milk ice cream reduces chemically induced mouse colon carcinogenesis. Journal of Dairy Science. http://dx.doi.org/10.3168/jds.2020-19979. PMid:33934866.

Balthazar, C. F., Silva, H. L. A., Esmerino, E. A., Rocha, R. S., Moraes, J., Carmo, M. A. V., Azevedo, L., Camps, I., Abud, K. D., Sant'Anna, Y., Franco, C., Freitas, R. M., Silva, M. Q., Raices, M. C., Escher, R. S. L., Granato, G. B., Senaka, D., Ranadheera, C., Nazarro, F., \& Cruz, A. G. (2018). The addition of inulin and Lactobacillus casei 01 in sheep milk ice cream. Food Chemistry, 246, 464-472. http://dx.doi. org/10.1016/j.foodchem.2017.12.002. PMid:29291874.

Barretta, C., Verruck, S., Maran, B. M., Maurício, L. dos S., Miotto, M., Vieira, C. R. W., \& Prudencio, E. S. (2019). Listeria monocytogenes survival in raw Atlantic salmon (Salmo salar) fillet under in vitro simulated gastrointestinal conditions by culture, qPCR and PMA-qPCR detection methods. LWT, 107, 132-137. http://dx.doi. org/10.1016/j.lwt.2019.03.015.

Begley, M., Gahan, C. G. M., \& Hill, C. (2005). The interaction between bacteria and bile. FEMS Microbiology Reviews, 29(4), 625-651. http:// dx.doi.org/10.1016/j.femsre.2004.09.003. PMid:16102595.

Botes, M., van Reenen, C. A., \& Dicks, L. M. T. (2008). Evaluation of Enterococcus mundtii ST4SA and Lactobacillus plantarum 423 as probiotics by using a gastro-intestinal model with infant milk formulations as substrate. International Journal of Food Microbiology, 128(2), 362-370. http://dx.doi.org/10.1016/j.ijfoodmicro.2008.09.016. PMid:18963159.

Boylston, T. D., Vinderola, C. G., Ghoddusi, H. B., \& Reinheimer, J. A. (2004). Incorporation of bifidobacteria into cheeses: Challenges and rewards. International Dairy Journal, 14(5), 375-387. http://dx.doi. org/10.1016/j.idairyj.2003.08.008.

Bustos, A. Y., Raya, R., Bru, E., de Valdez, G. F., \& Taranto, M. P. (2011). Application of fluorescent techniques to evaluate the survival of probiotic lactobacilli to bile acid. Biotechnology Letters, 33(7), 13891394. http://dx.doi.org/10.1007/s10529-011-0564-1. PMid:21365290.

Calvo-Lerma, J., Fornés-Ferrer, V., Heredia, A., \& Andrés, A. (2019). In vitro digestion models to assess lipolysis: The impact of the simulated conditions on gastric and intestinal $\mathrm{pH}$, bile salts and digestive fluids. Food Research International, 125(June), 108511. http://dx.doi.org/10.1016/j.foodres.2019.108511. PMid:31554063.

Chen, S., Cao, Y., Ferguson, L. R., Shu, Q., \& Garg, S. (2012). Flow cytometric assessment of the protectants for enhanced in vitro survival of probiotic lactic acid bacteria through simulated human gastro-intestinal stresses. Applied Microbiology and Biotechnology, 95(2), 345-356. http://dx.doi.org/10.1007/s00253-012-4030-3. PMid:22476171.

Fritzen-Freire, C. B., Prudêncio, E. S., Amboni, R. D. M. C., Pinto, S. S., Negrão-Murakami, A. N., \& Murakami, F. S. (2012). Microencapsulation of bifidobacteria by spray drying in the presence of prebiotics. Food Research International, 45(1), 306-312. http://dx.doi.org/10.1016/j. foodres.2011.09.020.

Ghandehari Yazdi, A. P., Barzegar, M., Ahmadi Gavlighi, H., Sahari, M. A., \& Mohammadian, A. H. (2020). Physicochemical properties and organoleptic aspects of ice cream enriched with microencapsulated pistachio peel extract. International Journal of Dairy Technology, 73(3), 570-577. http://dx.doi.org/10.1111/1471-0307.12698.

Grom, L. C., Rocha, R. S., Balthazar, C. F., Guimarães, J. T., Coutinho, N. M., Barros, C. P., Pimentel, T. C., Venâncio, E. L., Collopy, I. Jr., Maciel, P. M. C., Silva, P. H. F., Granato, D., Freitas, M. Q., Esmerino, E. A., Silva, M. C., \& Cruz, A. G. (2020). Postprandial glycemia in healthy subjects: Which probiotic dairy food is more adequate?
Journal of Dairy Science, 103(2), 1110-1119. http://dx.doi.org/10.3168/ jds.2019-17401. PMid:31785881.

Gu, M., Zhang, Z., Pan, C., Goulette, T. R., Zhang, R., Hendricks, G., McClements, D. J., \& Xiao, H. (2019). Encapsulation of Bifidobacterium pseudocatenulatum G7 in gastroprotective microgels: improvement of the bacterial viability under simulated gastrointestinal conditions. Food Hydrocolloids, 91, 283-289. http://dx.doi.org/10.1016/j.foodhyd.2019.01.040.

Guo, Z., Wang, J., Yan, L., Chen, W., Liu, X., \& Zhang, H. (2009). In vitro comparison of probiotic properties of Lactobacillus casei Zhang, a potential new probiotic, with selected probiotic strains. Lebensmittel-Wissenschaft + Technologie, 42(10), 1640-1646. http:// dx.doi.org/10.1016/j.lwt.2009.05.025.

Hill, C., Guarner, F., Reid, G., Gibson, G. R., Merenstein, D. J., Pot, B., Morelli, L., Canani, R. B., Flint, H. J., Salminen, S., Calder, P. C., \& Sanders, M. E. (2014). The International Scientific Association for Probiotics and Prebiotics consensus statement on the scope and appropriate use of the term probiotic. Nature Reviews. Gastroenterology \& Hepatology, 11(8), 506-514. http://dx.doi. org/10.1038/nrgastro.2014.66. PMid:24912386.

Homayouni, A., Azizi, A., Javadi, M., Mahdipour, S., \& Ejtahed, H. (2012). Factors influencing probiotic survival in ice cream: A review. International Journal of Dairy Science, 7(1), 1-10. http://dx.doi. org/10.3923/ijds.2012.1.10.

Hoover, D. G. (2014). Bifidobacterium. Encyclopedia of Food Microbiology: Second Edition, 1, 216-222. https://doi.org/10.1016/B978-0-12384730-0.00033-1.

Janer, C., Peláez, C., \& Requena, T. (2004). Caseinomacropeptide and whey protein concentrate enhance Bifidobacterium lactis growth in milk. Food Chemistry, 86(2), 263-267. http://dx.doi.org/10.1016/j. foodchem.2003.09.034.

Kalicka, D., Znamirowska, A., Pawlos, M., Buniowska, M., \& Szajnar, K. (2019). Physical and sensory characteristics and probiotic survival in ice cream sweetened with various polyols. International Journal of Dairy Technology, 72, 456-465. http://dx.doi.org/10.1111/1471-0307.12605.

Kurdi, P., Kawanishi, K., Mizutani, K., \& Yokota, A. (2006). Mechanism of growth inhibition by free bile acids in lactobacilli and bifidobacteria. Journal of Bacteriology, 188(5), 1979-1986. http://dx.doi.org/10.1128/ JB.188.5.1979-1986.2006.

Liao, S. F., \& Nyachoti, M. (2017). Using probiotics to improve swine gut health and nutrient utilization. Animal Nutrition, 3(4), 331-343. http://dx.doi.org/10.1016/j.aninu.2017.06.007. PMid:29767089.

Madureira, A. R., Amorim, M., Gomes, A. M., Pintado, M. E., \& Malcata, F. X. (2011). Protective effect of whey cheese matrix on probiotic strains exposed to simulated gastrointestinal conditions. Food Research International, 44(1), 465-470. http://dx.doi.org/10.1016/j. foodres.2010.09.010.

Magariños, H., Selaive, S., Costa, M., Flores, M., \& Pizarro, O. (2007). Viability of probiotic micro-organisms (Lactobacillus acidophilus La-5 and Bifidobacterium animalis subsp. lactis Bb-12) in ice cream. International Journal of Dairy Technology, 60(2), 128-134. http:// dx.doi.org/10.1111/j.1471-0307.2007.00307.x.

Mehditabar, H., Razavi, S. M. A., \& Javidi, F. (2020). Influence of pumpkin puree and guar gum on the bioactive, rheological, thermal and sensory properties of ice cream. International Journal of Dairy Technology, 73(2), 447-458. http://dx.doi.org/10.1111/1471-0307.12658.

Minekus, M., Alminger, M., Alvito, P., Ballance, S., Bohn, T., Bourlieu, C., Carrière, F., Boutrou, R., Corredig, M., Dupont, D., Dufour, C., Egger, L., Golding, M., Karakaya, S., Kirkhus, B., Le Feunteun, S., Lesmes, U., MacIerzanka, A., MacKie, A., Marze, S., McClements, D. J., Ménard, O., Recio, I., Santos, C. N., Singh, R. P., Vegarud, G. E., Wickham, M. S., Weitschies, W., \& Brodkorb, A. (2014). A 
standardised static in vitro digestion method suitable for food-an international consensus. Food \& Function, 5(6), 1113-1124. http:// dx.doi.org/10.1039/C3FO60702J. PMid:24803111.

Moens, F., Verce, M., \& De Vuyst, L. (2017). Lactate- and acetate-based cross-feeding interactions between selected strains of lactobacilli, bifidobacteria and colon bacteria in the presence of inulin-type fructans. International Journal of Food Microbiology, 241, 225-236. http://dx.doi.org/10.1016/j.ijfoodmicro.2016.10.019. PMid:27810444.

Mousavi Khaneghah, A., Abhari, K., Eş, I., Soares, M. B., Oliveira, R. B. A., Hosseini, H., Rezaei, M., Balthazar, C. F., Silva, R., Cruz, A. G., Ranadheera, C. S., \& Sant'Ana, A. S. (2020). Interactions between probiotics and pathogenic microorganisms in hosts and foods: a review. Trends in Food Science \& Technology, 95, 205-218. http:// dx.doi.org/10.1016/j.tifs.2019.11.022.

Munoz, I. de B., Machado Canella, M. H., Verruck, S., Olivera Muller, C. M., de Liz, G. R., Castanho Amboni, R. D. M., \& Prudencio, E. S. (2017). Potential of milk freeze concentration for the production of functional fresh cheeses. Advance Journal of Food Science and Technology, 13(5), 196-209. http://dx.doi.org/10.19026/ajfst.13.5069.

Muñoz, I. de B., Rubio, A., Blanco, M., Raventós, M., Hernández, E., \& Prudêncio, E. S. (2019). Progressive freeze concentration of skimmed milk in an agitated vessel: Effect of the coolant temperature and stirring rate on process performance. Food Science \& Technology International, 25(2), 150-159. http://dx.doi. org/10.1177/1082013218803263. PMid:30286622.

Petzold, G., Moreno, J., Lastra, P., Rojas, K., \& Orellana, P. (2015). Block freeze concentration assisted by centrifugation applied to blueberry and pineapple juices. Innovative Food Science \& Emerging Technologies, 30, 192-197. http://dx.doi.org/10.1016/j.ifset.2015.03.007.

Picot, A., \& Lacroix, C. (2004). Encapsulation of bifidobacteria in whey protein-based microcapsules and survival in simulated gastrointestinal conditions and in yoghurt. International Dairy Journal, 14(6), 505515. http://dx.doi.org/10.1016/j.idairyj.2003.10.008.

Ranadheera, C. S., Evans, C. A., Adams, M. C., \& Baines, S. K. (2012). In vitro analysis of gastrointestinal tolerance and intestinal cell adhesion of probiotics in goat's milk ice cream and yogurt. Food Research International, 49(2), 619-625. http://dx.doi.org/10.1016/j.foodres.2012.09.007.
Rodrigues, D., Rocha-Santos, T. A. P., Freitas, A. C., Duarte, A. C., Rocha-Santos, T. A. P., Freitas, A. C., \& Gomes, A. M. P. (2012). Analytical strategies for characterization and validation of functional dairy foods. Trends in Analytical Chemistry, 41, 27-45. http://dx.doi. org/10.1016/j.trac.2012.08.009.

Ruas-Madiedo, P., Gueimonde, M., Arigoni, F., De Los ReyesGavilán, C. G., \& Margolles, A. (2009). Bile affects the synthesis of exopolysaccharides by Bifidobacterium animalis. Applied and Environmental Microbiology, 75(4), 1204-1207. http://dx.doi. org/10.1128/AEM.00908-08. PMid:19088310.

Shah, N. P. (2007). Functional cultures and health benefits. International Dairy Journal, 17(11), 1262-1277. http://dx.doi.org/10.1016/j. idairyj.2007.01.014.

Souza, C. H. B., Gioielli, L. A., \& Saad, S. M. I. (2017). Inulin increases Bifidobacterium animalis $\mathrm{Bb}-12$ in vitro gastrointestinal resistance in margarine. Lebensmittel-Wissenschaft + Technologie, 79, 205-212. http://dx.doi.org/10.1016/j.lwt.2017.01.032.

Verruck, S., Carvalho, M. W., Liz, G. R., Amante, E. R., Vieira, C. R. W., Amboni, R. D., \& Prudencio, E. S. (2017). Survival of Bifidobacterium BB-12 microencapsulated with full-fat goat's milk and prebiotics when exposed to simulated gastrointestinal conditions and thermal treatments. Small Ruminant Research, 153, 48-56. http://dx.doi. org/10.1016/j.smallrumres.2017.05.008.

Vinderola, C. G., \& Reinheimer, J. A. (2000). Enumeration of Lactobacillus casei in the presence of L. acidophilus, bifidobacteria and lactic starter bacteria in fermented dairy products. International Dairy Journal, 10(4), 271-275. http://dx.doi.org/10.1016/S09586946(00)00045-5.

Xu, Y., Cui, Y., Yue, F., Liu, L., Shan, Y., Liu, B., Zhou, Y., \& Lü, X. (2019). Exopolysaccharides produced by lactic acid bacteria and Bifidobacteria: Structures, physiochemical functions and applications in the food industry. Food Hydrocolloids, 94, 475-499. http://dx.doi. org/10.1016/j.foodhyd.2019.03.032.

Zendeboodi, F., Khorshidian, N., Mortazavian, A. M., \& Cruz, A. G. (2020). Probiotic: conceptualization from a new approach. Current Opinion in Food Science, 32, 103-123. http://dx.doi.org/10.1016/j. cofs.2020.03.009. 